\begin{abstract}
AIms: To determine the level of serum procalcitonin and cerebrospinal fluid cytokines in children with bacterial or viral meningitis and to document the use of these parameters in differential diagnosis.

Results: Before the start of antibiotic treatment, serum procalcitonin and tumor necrosis factor alpha levels were found to be higher in acute bacterial meningitis compared with viral meningitis and with the control group. Similarly, cerebrospinal fluid interleukin-6 levels were found to be significantly higher in children with acute bacterial meningitis compared with viral meningitis. However, no significant difference was determined between groups in respect to the cerebrospinal fluid interleukin-8 level. Conclusion: Serum procalcitonin and cerebrospinal fluid tumor necrosis factor alpha levels can be used in the early diagnosis of bacterial meningitis. Similarly, they may be useful adjuncts in differential diagnosis of bacterial and viral meningitis.
\end{abstract}

Key words: Meningitis, Procalcitonin, Tumor necrosis factor alpha, Interleukin-6, Interleukin-8, Children

\section{Serum procalcitonin and cerebrospinal fluid cytokines level in children with meningitis}

\author{
Erdal Taskın ${ }^{1}$, Mehmet Turgut ${ }^{1}$, Mehmet Kılıc ${ }^{1}$, \\ Handan Akbulut ${ }^{2}$ and A. Denizmen Aygun ${ }^{1, C A}$
}

${ }^{1}$ Department of Pediatrics and ${ }^{2}$ Department of Immunology, Medical Faculty of Firat University, Elazig, Turkiye

\author{
${ }^{\mathrm{CA}}$ Corresponding Author \\ Tel: +90 42423335 55/1610 \\ Fax: +904242387688 \\ E-mail: daygun@firat.edu.tr
}

\section{Introduction}

Despite the advances in diagnosis and treatment of infectious diseases, meningitis and encephalitis are still considered to be important causes of mortality and morbidity. ${ }^{1}$ In efforts to decrease the morbidity and mortality related to bacterial meningitis, having an early diagnosis and starting immediate empirical therapy are the key factors. In the early phases of acute bacterial and viral meningitis, signs and symptoms are often non-specific and it is not always possible to make a differential diagnosis on the basis of routine examination of cerebrospinal fluid (CSF). In untreated bacterial meningitis, Gram staining of CSF reveals bacteria in about $50-80 \%$ of cases and cultures are positive in at least $85 \%$ of cases. However, sensitivity of both tests is less than $50 \%$ in patients who are already on antibiotic treatment. ${ }^{2,3}$ Waiting for at least 2 days was recommended to identify bacterial growth in CSF cultures, whereas this period is 3-8 days for viral cultures. ${ }^{4,5}$ Moreover, identifying the frequently encountered viral agents via polymerase chain reaction is not always possible in every institution. ${ }^{6}$ Therefore, intensive research has been carried out to find new and rapid diagnostic methods for differential diagnosis of bacterial and viral meningitis.

Procalcitonin (PCT), which is a calcitonin propeptide, is supposed to be synthesized in C cells of the thyroid gland ${ }^{7}$ and secreted from leukocytes of the peripheral blood. The secretion of PCT was found to increase in the presence of bacterial lipopolysaccharides and cytokines that are associated with sepsis., 8
It was previously shown that serum PCT levels increase during the course of bacterial, parasitic or fungal infections, but remain normal or slightly increase in viral infections and inflammatory reactions that are not infectious. ${ }^{10,11}$

Cytokines are hormone-like proteins and function by binding to their specific receptors. ${ }^{12}$ There is emerging evidence that the level of tumor necrosis factor alpha (TNF- $\alpha$ ), interleukin (IL)-6 and IL-8 may play important roles in pathogenesis of meningitis, and are successfully used in early diagnosis as well as differential diagnosis of bacterial and viral meningitis. ${ }^{13-16}$

The aim of the present study was to determine the role of serum PCT and CSF IL-6, IL- 8 and TNF- $\alpha$ levels in early diagnosis of bacterial meningitis and to document their efficacy in differential diagnosis of viral and bacterial meningitis

\section{Materials and methods}

A total of 44 children with meningitis admitted to a University Hospital were followed in this prospective study. The mean age was $60.1 \pm 31.3$ months and the age range was 4-160 months. Twenty-two children were diagnosed as bacterial meningitis and the other 22 children as viral meningitis. The control group was revealed by 10 children whose age range was between 6 and 132 months.

Informed signed consent was obtained from parents for their children to participate in the study, and 
the Ethic Committee of Medical faculty of Firat University approved the protocol of this study.

Meningitis was diagnosed according to evaluation of history, physical examination, CSF laboratory findings, identification of bacterial agents in CSF Gram staining and cultures. Meningitis is defined as bacterial if the CSF laboratory findings (increased protein $>2 \mathrm{~g} / \mathrm{l}$, decreased glucose ratio $<0.4$, and leukocyte count $>1500 \times 10^{6} / 1$ and polymorph nuclear leukocyte domination), identification of bacterial agents in Gram staining and/or bacterial culture were positive; or was defined as viral if the viral culture, serological testing, pleocytosis, or reverse transcriptase polymerase chain reaction were positive and the bacterial culture was negative.

The control group was defined by an absence of inflammatory cells in CSF (cell count $<5 \times 10^{6} / 1$ and sterile for bacteriologic and virologic findings) on afebrile and meningeal sign-positive children. Eight children were diagnosed with epilepsy and two with relapse-free acute lymphoblastic leukemia.

Blood serum samples were taken from all cases at the time of diagnosis and at $48-72 \mathrm{~h}$ of treatment. The blood glucose level, peripheral leukocyte count, erythrocyte sedimentation rate and serum PCT in blood serum samples and the protein, glucose, number and type of cells, TNF- $\alpha$, IL- 6 and IL- 8 levels in CSF samples were simultaneously investigated. These parameters were investigated only once at the time of diagnosis in the control group. Symptoms and findings at the time of diagnosis, demographical data, peripheral leukocyte count, erythrocyte sedimentation rate, and follow-up body temperature (body temperature $>37.8^{\circ} \mathrm{C}$, armpit) of cases were monitored.

Collected serum and CSF samples were centrifuged at 2000 rotation for $15 \mathrm{~min}$ and stored at $-80^{\circ} \mathrm{C}$ until the analysis of cytokines. Cerebrospinal fluid IL-6, IL-8 and TNF- $\alpha$ levels were measured using commercial enzyme 'immunoassay' kits (ACCUCYTE human TNF alpha ELISA, ACCUCYTE human IL-6 ELISA and ACCUCYTE human IL-8 ELISA; Cytimmune Science Inc., Rockville, MD, USA). Serum PCT levels were studied by the immunoluminometric method in Analyzer luminometer equipment using the Lumitest kit (Lumitest PCT kits BRAHMS Diagnostica, Berlin, Germany).

Statistical analysis of data was carried out in a Windows setting using the SPSS 10.0 program. Differences between groups in continuous variables were tested for significance with the Mann-Whitney test. Differences in frequencies of findings between groups were analyzed by Fischer's exact test. The Spearman correlation coefficient $(r)$ was used to evaluate the relation between specific variables. Two-tailed $p \leq 0.05$ was considered significant.

\section{Results}

Of the 44 cases with meningitis, 29 (65.9\%) were males and 15 (34.1\%) were females. The mean age of the patients was $( \pm$ standard deviation) $65.29 \pm 51.91$ months (Table 1). There was no difference between bacterial and viral meningitis groups in respect to mean age $(p>0.05)$. Clinical characteristics and laboratory findings in both groups are summarized in Table 1. The most common symptoms at the time of diagnosis in all study groups were fever (100\%), nausea or vomiting (40.9\%) and convulsion (31.8\%).

CSF findings of patients with bacterial and viral meningitis, and of the control group, are presented in Table 2. Bacterial culture revealed Neisseria meningitidis in eight cases, Streptococcus pneumoniae in eight cases, Haemophilus influenzae in four cases, Escherichia coli in one case, and Pseudomonas aeuroginosae in one case. Six patients had viral meningitis while experiencing an episode of mumps, two developed the diseases simultaneously with measles, and two showed viral meningitis during an episode of varicella, which were all verified by CSF serology. Additionally, reverse transcriptase polymerase chain reaction using the previously defined primers detected the presence of RNA of enteroviruses in CSF for 12 patients.

Serum PCT and CSF cytokine levels in all groups are summarized in Table 3. At the time of diagnosis, patients with bacterial meningitis had increased serum PCT, CSF IL-6, IL-8 and TNF- $\alpha$ levels compared with the control group $(p<0.001)$. A similar comparison between bacterial and viral meningitis at the time of diagnosis also revealed increased serum PCT and CSF cytokines levels in bacterial meningitis patients (PCT, $p<0.001$; CSF IL-6, $p<0.05$; and TNF- $\alpha, p<0.001)$. No significant difference was determined between bacterial and viral meningitis groups in respect to the CSF IL-8 level. Similarly, there was no significant difference between viral meningitis and control groups when serum PCT and CSF TNF- $\alpha$ levels were compared $(p>0.05)$. IL-6 and IL-8 levels in CSF were significantly higher in viral meningitis groups compared with the control group $(p<0.01)$. However, the assessment of the same parameters at $48-72 \mathrm{~h}$ after the start of treatment showed also significantly higher levels of serum PCT and CSF TNF- $\alpha$, IL-6 $(p<0.001)$ and IL-8 $(p<0.01)$ in the bacterial meningitis group than in the viral meningitis group. At $48-72 \mathrm{~h}$ after the start of treatment the decrease of serum PCT and CSF TNF$\alpha$, IL- 6 and IL- 8 levels of the bacterial meningitis group was statistically significant compared with levels at the start of treatment $(p<0.001)$.

A strong correlation between IL- 6 and IL- 8 in the bacterial meningitis group was evaluated $(r=0.957$, $p=0.001)$. There was no correlation among other 
Table 1. Clinical and demographic features of all groups

\begin{tabular}{|c|c|c|c|}
\hline & $\begin{array}{l}\text { Bacterial } \\
\text { meningitis }\end{array}$ & $\begin{array}{c}\text { Viral } \\
\text { meningitis }\end{array}$ & Control \\
\hline \multicolumn{4}{|l|}{ Gender } \\
\hline Female & $9(40.9)$ & $6(27.3)$ & $4(40.0)$ \\
\hline Male & $13(59.1)$ & $16(72.7)$ & $6(60.0)$ \\
\hline Age (months) & $56.6 \pm 25.5$ & $74.3 \pm 30.3$ & $60.1 \pm 27.6$ \\
\hline \multicolumn{4}{|l|}{ Clinical findings } \\
\hline Fever & $22(100.0)$ & $22(100.0)$ & $0(0.0)$ \\
\hline Nausea or vomiting & $6(27.2)$ & $12(54.5)$ & $1(10.0)$ \\
\hline Headhache & $11(50.0)$ & $6(27.2)$ & $1(10.0)$ \\
\hline Convulsion & $7(31.8)$ & $7(31.8)$ & $9(90.0)$ \\
\hline Parotitis & $0(0.0)$ & $6(27.2)$ & $0(0.0)$ \\
\hline \multicolumn{4}{|c|}{ Laboratory findings } \\
\hline $\begin{array}{l}\text { Erytrocyte sedimentation rate }(\mathrm{mm} / \mathrm{h}) \\
\text { Leukocyte count }\left(/ \mathrm{mm}^{3}\right)\end{array}$ & $\begin{array}{l}30.9 \pm 29.5 \\
16.28 \pm 9.67 \times 10^{9}\end{array}$ & $\begin{array}{l}18.9 \pm 12.5 \\
8.99 \pm 5.92 \times 10^{9}\end{array}$ & $\begin{array}{l}18.0 \pm 8.0 \\
5.63 \pm 1.41 \times 10^{9}\end{array}$ \\
\hline
\end{tabular}

Numbers in parantheses are percentages.

parameters. Also no correlation was observed among PCT and CSF cytokines in the viral meningitis group and the control group.

\section{Discussion}

Previous studies have revealed that in most children and adults the serum PCT level is increased in acute bacterial meningitis cases, but remains normal in viral meningitis. ${ }^{17,18}$ Thus it was concluded that the best diagnostic parameter in differential diagnosis of bacterial and viral meningitis in children is serum PCT, whereas the PCT increase in the CSF was considered non-specific and can only be used in the follow-up of the disease. Since PCT decreases with successful treatment and becomes unidentifiable, it may be helpful in follow-up. ${ }^{17-20}$
In the present study, a significant increase was found in the serum PCT of bacterial meningitis cases at the time of diagnosis in comparison with the control group. However, there was no such increase in the viral meningitis group. Procalcitonin levels measured at $48-72 \mathrm{~h}$ of the treatment were found to be less than the level measured at the beginning of treatment, but did not return to normal values as in the control group. This finding suggests that the serum PCT level continues to be high for $48-72 \mathrm{~h}$ (despite treatment) and can be used for diagnosis for at least $48 \mathrm{~h}$. Nevertheless, it is more reliable in diagnosis when measured before starting any treatment. Normally, PCT is very low in circulation or in serum of healthy subjects as well as in patients with inflammatory diseases, reaches high concentrations in patients with severe bacterial infection and decreases rapidly after appropriate antibiotic therapy. ${ }^{21}$

Table 2. Laboratory findings of all groups

\begin{tabular}{|c|c|c|c|c|c|c|}
\hline & \multicolumn{2}{|c|}{ Bacterial meningitis } & \multicolumn{2}{|c|}{ Viral meningitis } & \multirow[t]{2}{*}{ Control $^{\mathrm{e}}$} & \multirow[t]{2}{*}{$p$ value } \\
\hline & $\begin{array}{l}\text { Value at time } \\
\text { of diagnosis }\end{array}$ & $\begin{array}{l}\text { Value at } \\
48-72 \mathrm{~h}^{\mathrm{b}}\end{array}$ & $\begin{array}{l}\text { Value at time } \\
\text { of diagnosis }\end{array}$ & $\begin{array}{l}\text { Value at } \\
48-72 \mathrm{~h}^{\mathrm{d}}\end{array}$ & & \\
\hline $\begin{array}{l}\text { CSF Leukocyte } \\
\text { count (cells/l) }\end{array}$ & $953 \pm 268 \times 10^{6}$ & $283 \pm 80 \times 10^{6}$ & $174 \pm 130 \times 10^{6}$ & $75 \pm 56 \times 10^{6}$ & $0.0 \pm 0.0 \times 10^{6}$ & $\begin{array}{l}p<0.01, \mathrm{a} \text { and } \mathrm{b}, \\
\mathrm{a} \text { and } \mathrm{c}, \mathrm{b} \text { and } \mathrm{d} \\
p<0.001, \mathrm{a} \text { and } \mathrm{e} \\
p<0.05, \mathrm{c} \text { and } \mathrm{d}, \\
\mathrm{c} \text { and } \mathrm{e}\end{array}$ \\
\hline $\begin{array}{l}\text { CSF leukocyte } \\
\text { differential count } \\
\text { fraction }(\%)\end{array}$ & $0.79 \pm 0.30$ & $0.83 \pm 0.18$ & $0.18 \pm 0.12$ & $0.07 \pm 0.01$ & $0.00 \pm 0.00$ & $\begin{array}{l}p<0.01, \text { a and } c \\
b \text { and } d\end{array}$ \\
\hline CSF protein $(\mathrm{mg} / \mathrm{l})$ & $2.04 \pm 1.33$ & $1.09 \pm 0.68$ & $0.51 \pm 0.20$ & $0.54 \pm 0.24$ & $0.28 \pm 0.11$ & $\begin{array}{l}p<0.001, \text { a and } \mathrm{e} \\
p<0.01, \mathrm{a} \text { and } \mathrm{c}, \\
\mathrm{a} \text { and } \mathrm{b} \\
p<0.001, \text { a and } \mathrm{e} \\
p<0.05, \mathrm{~b} \text { and } \mathrm{d}, \\
\mathrm{c} \text { and } \mathrm{e}\end{array}$ \\
\hline CSF glucose (mmol/l) & $1.71 \pm 1.22$ & $2.36 \pm 0.67$ & $3.19 \pm 0.93$ & $3.11 \pm 0.93$ & $4.18 \pm 0.69$ & $\begin{array}{l}p<0.01, \text { a and } c, \\
c \text { and } \mathrm{e} \\
p<0.05, \text { a and } b, \\
a \text { and } e\end{array}$ \\
\hline
\end{tabular}

Data presented as mean \pm standard deviation. 
Table 3. Serum PCT and CSF cytokines values of all group

\begin{tabular}{|c|c|c|c|c|c|c|}
\hline & \multicolumn{2}{|c|}{ Bacterial meningitis } & \multicolumn{2}{|c|}{ Viral meningitis } & \multirow[t]{2}{*}{ Control $^{\mathrm{e}}$} & \multirow[t]{2}{*}{$p$ value } \\
\hline & $\begin{array}{l}\text { Value at time } \\
\text { of diagnosis }^{a}\end{array}$ & $\begin{array}{l}\text { Value at } \\
48-72 \mathrm{~h}^{\mathrm{b}}\end{array}$ & $\begin{array}{l}\text { Value at time } \\
\text { of diagnosis }\end{array}$ & $\begin{array}{l}\text { Value at } \\
48-72 \mathrm{~h}^{\mathrm{d}}\end{array}$ & & \\
\hline PCT (ng/l) & $75.8 \pm 29.8$ & $35.7 \pm 19.6$ & $0.3 \pm 0.2$ & $0.3 \pm 0.1$ & $0.3 \pm 0.2$ & $\begin{array}{l}p<0.001, \text { a and } b, a \text { and } c \text {, } \\
a \text { and } e, b \text { and } d\end{array}$ \\
\hline IL-6 (pg/ml) & $349.3 \pm 169.2$ & $234.0 \pm 195.0$ & $168.1 \pm 143.8$ & $108.0 \pm 75.2$ & $17.5 \pm 5.4$ & $\begin{array}{l}p<0.001, \mathrm{a} \text { and } \mathrm{b}, \mathrm{a} \text { and } \mathrm{e} \\
\mathrm{b} \text { and d, } \mathrm{c} \text { and } \mathrm{d} \\
p<0.01, \mathrm{c} \text { and } \mathrm{e} \\
p<0.05, \text { a and } \mathrm{c}\end{array}$ \\
\hline IL-8 (pg/ml) & $194.4 \pm 98.7$ & $154.1 \pm 146.1$ & $152.9 \pm 75.3$ & $109.0 \pm 53.3$ & $128.5 \pm 20.8$ & $\begin{array}{l}p<0.001, \text { and } e, c \text { and } d, \\
c \text { and } e \\
p<0.01, \text { a and } b, b \text { and } d\end{array}$ \\
\hline TNF- $\alpha(p g / m l)$ & $26.5 \pm 22.6$ & $12.4 \pm 10.2$ & $1.6 \pm 0.3$ & $1.7 \pm 0.6$ & $1.7 \pm 0.5$ & $\begin{array}{l}p<0.001, a \text { and } b, a \text { and } c \text {, } \\
a \text { and } e, b \text { and } d\end{array}$ \\
\hline
\end{tabular}

Data presented as mean \pm standard deviation.

It was shown that CSF TNF- $\alpha$ levels were high in acute bacterial meningitis, but generally normal in viral meningitis. ${ }^{14-16,22}$ We observed similar findings in our study. Previous studies revealed that the CSF TNF- $\alpha$ concentration increased in experimental bacterial meningitis models; however, it remained at very low levels in the blood. ${ }^{13}$ However, in several clinical studies, TNF- $\alpha$ is high increased in the serum of patients with bacterial meningitis. ${ }^{13,22,23}$

In our study, the CSF TNF- $\alpha$ level was also higher in acute bacterial meningitis cases than those in viral meningitis and the control group. Although the TNF$\alpha$ level decreased at $48-72 \mathrm{~h}$, they were still higher than those in the viral meningitis and control groups. None of the viral meningitis cases showed an increase in the TNF- $\alpha$ level and the difference was non-significant compared with the control group. These findings suggest that TNF- $\alpha$ can be used to differentiate bacterial and viral meningitis. Although TNF- $\alpha$ is considered a sensitive and reliable marker in diagnosis of bacterial meningitis, it is not as much practical as serum PCT in the diagnosis. This is because measurement of CSF TNF- $\alpha$ is much more invasive, which requires lumbar punction. Additionally, PCT is stable at room temperature, can be observed regularly in blood samples and can be measured together with routine variables. Serum PCT results can be obtained in $2 \mathrm{~h}$ and can be conducted with only $20 \mu \mathrm{l}$ of serum. We observed a gradual decrease in TNF- $\alpha$ levels after antibiotic treatment, and this shows that TNF- $\alpha$ can be used to follow the progression of disease and to monitor the effect of antibiotics on outcome of meningitis. However, further research is needed to determine the exact role of TNF- $\alpha$ measurements in bacterial meningitis.

Cerebrospinal fluid IL-8 measurement was increased in patients with both bacterial meningitis and viral meningitis. However, it is not useful in differential diagnosis of bacterial and viral meningitis. Although some authors reported that neither IL-8 nor TNF- $\alpha$ and any other CSF parameter can be used in differential diagnosis of meningitis, ${ }^{24-26}$ Azuma et al . found increased CSF TNF- $\alpha$ only in bacterial meningitis cases. Thus, they believe that the CSF cytokine level could be used as a means of rapid diagnosis. ${ }^{27}$ Our findings suggested that serum PCT and CSF cytokines (IL-6, IL-8 and TNF- $\alpha$ ) can be used in diagnosis of meningitis; moreover, serum PCT and CSF IL- 6 and TNF- $\alpha$ can be measured to differentiate bacterial meningitis from viral meningitis.

Mastrioanni et al. ${ }^{28}$ found that the IL-8 level was high both in tuberculosis meningitis patients and in patients with bacterial meningitis. However, IL-8 remained high for months in tuberculosis meningitis as opposed to bacterial meningitis. ${ }^{29}$ Seki et al. ${ }^{30}$ found high levels of CSF IL-8 in bacterial meningitis cases and showed that CSF IL-8 levels were much lower in viral meningitis patients. In several studies it was also shown that the CSF IL-8 level increased in viral meningitis cases, although the increase was not as much as that in bacterial meningitis. Nevertheless, the CSF IL-8 level could be used in meningitis diagnosis. $^{29-31}$

In this study, IL-8 levels at the time of diagnosis of meningitis were highest in the bacterial meningitis group. It was also increased in the viral meningitis group when compared with the control group. No statistically significant difference was found between bacterial and viral meningitis groups in terms of the CSF IL-8 level at the time of diagnosis and 48-72 h. Our findings revealed that the CSF IL- 8 level can be useful in diagnosis of meningitis; however, it was not a useful marker in distinguishing between bacterial and viral meningitis.

In conclusion, this is the first study using a repertoire of cytokines and PCT in human serum and CSF to diagnose meningitis and to determine their roles in differential diagnosis of viral and bacterial meningitis. In the presence of meningeal symptoms, measurements of PCT in the serum and TNF- $\alpha$ and IL- 6 in the CSF could be an early and important diagnostic marker used in differential diagnosis of bacterial and viral meningitis as well as other diseases causing meningeal irritation. Serum 
PCT measurement does not require any invasive intervention such as lumbar puncture and, with its stable molecular structure in serum, it can be frequently measured in serum for the diagnosis and follow-up of bacterial meningitis, making this parameter more useful than TNF- $\alpha$ and IL- 6 in clinical practice.

\section{References}

1. Baraff LJ, Lee SI, Schriger DL. Outcomes of bacterial meningitis in children: a meta-analysis. Pediatr Infect Dis J 1993; 12: 389-394.

2. Lindquist L, Linne T, Hansson LO, Kalin M, Axelsson G. Value of cerebrospinal fluid analysis in the differential diagnosis of meningitis: a study 710 patients with suspected central nervous system infection. Eur J Clin Microbiol Infect Dis 1988; 7: 374-380.

3. Katz SL. Viral infections of the central nervous. In: Gershon AA, Hotez PJ, eds. Krugman's Infectious Disease Children, St Louis, MO: C.V Mosby, 1998: 650-666.

4. Marton KI, Gean AD. The spinal tap: a new look at an old test. Ann Intern Med 1986; 104: $840-848$

5. Rotbart HA. Viral meningitis and aseptic menegitis syndrome. In: Scheld WN, Whitley RJ, Durack DT, eds. Infections of the Central Nervous System, 2nd edn, Philadelphia, PA: Lippincott-Raven, 1997: 23-46.

6. Cassady KA, Whitley RJ. Pathogenesis and pathophisysiology of viral infections of the central nervous system. In: Scheld WN, Whitley RJ, Durack DT, eds. Infections of the Central Nervous System, 2nd edn, Philadelphia, PA: Lippincott-Raven, 1997: 7-22

7. Jacops JW, Lund PK, Potts JT Jr, Bell NH, Habener JF. Procalcitonin is a glycoprotein. J Biol Chem 1981; 256: 2803-2807.

8. Oberhoffer M, Stonans I, Russwurm S, et al. Procalcitonin expression in human peripheral blood mononuclear cells and its modulation by lipopolysaccharides and sepsis-related cytokines in vitro. J Lab Clin Med 1999; 134: 49-55.

9. Assicot M, Gendrel D, Carsin H, Raymond J, Guilbaud J, Bohuon C. High serum procalcitonin concentrations in patients with sepsis and infection. Lancet 1993; 341: 515-518

10. Meisner M. PCT-procalcitonin: A New and Innovative Parameter in Diagnosis of Infections, Berlin: BRAHMS Diagnostica, 1996: 14-60.

11. Huber W, Schweigart U, Bottermann P. Failure of PCT to indicate severe fungal infection in two immunodeficient patients. Infection 1997; 25: $377-378$

12. Akalin $\mathrm{H}$, Akdis AC, Mistik R, Helvaci S, Kilicturgay K. Cerebrospinal fluid interleukin-1 beta/interleukin-1 receptor antagonist balance and tumor necrosis factor-alpha concentrations in tuberculous, viral and acute bacterial meningitis. Scand J Infect Dis 1994; 26: 667-674.

13. Mustafa MM, Ramilo O, Saez-Liorens X, Mertsola J, Mc Cracken GH Jr. Role of tumor necrosis factor alpha (cachectin) in experimental and clinical bacterial meningitis. Pediatr Infect Dis J 1989; 8: 907-908.

14. Glimaker M, Kragsbjerg P, Forsgren M, Olcen P. Tumor necrosis factoralpha (TNF-alpha) in cerebrospinal fluid from patients with meningitis of different etiologies: High levels of TNF-alpha indicate bacterial meningitis. J Infect Dis 1993; 167: 882-889.
15. Kepa L, Adamek B, Stolarz W. Diagnostic value of tumor necrosis factoralpha (TNF-alpha) determination in cerebrospinal fluid (CSF) in the course of neural infections. Neurol Neuruchir Pol 1998; 32: 533-542.

16. Ceyhan M, Kanra G, Ecevit Z, et al. Tumor necrosis factor-alpha and interleukin-1 beta levels in children with bacterial, tuberculous and aseptic meningitis. Turk J Pediatr 1997; 39: 177-184.

17. Gendrel D, Raymond J, Assicot M, et al. Measurement of procalcitonin levels in children with bacterial or viral meningitis. Clin Infect Dis 1997; 24: $1240-1242$

18. Schwarz S, Bertram M, Schwab S, Andrassy K, Hacke W. Serum procalcitonin levels in bacterial and abacterial meningitis. Crit Care Med 2000; 28: $1828-1832$

19. Monneret G, Labaune JM, Isaac C, Bienvenu F, Putet G, Bienvenu J. Procalcitonin and C-reactive protein levels in neonatal infections. Acta Paediatr 1997; 86: 209-212.

20. Viallon A, Zeni F, Lambert C, et al. High sensitivity and specificity of serum procalcitonin levels in adults with bacterial meningitis. Clin Infect Dis 1999; 28: 1313-136.

21. Gendrel D, Bobuon C. Procalcitonin, a marker of bacterial infection. Infection 1997; 25: 133-134

22. Moller B, Mogensen SC, Wendelboe P, Bendtzen K, Petersen CM. Bioactive and inactive forms of tumor necrosis factor-alpha in spinal fluid from patients with meningitis. J Infect Dis 1991; 163: 886-889.

23. Waage A, Halstensen A, Shalaby R, Brandtzaeg P, Kierulf P, Espevik T. Local production of tumor necrosis factor-alpha, interleukin-1 and interleukin 6 in meningococcal meningitis. Relation to the inflammatory response. J Exp Med 1989; 170: 1859-1867.

24. Houssiau FA, Bukasa K, Sindic CJ, Van Damme J, Van Snick J. Elevated levels of the $26 \mathrm{~K}$ human hybridoma growth factor (Interleukin 6) in cerebrospinal fluid of patients with acute infection of central nervous system. Clin Exp Immunol 1988; 71: 320-323.

25. Torre D, Zeroli C, Ferraro G, et al. Cerebrospinal fluid levels of IL-6 in patients with acute infections of the central nervous system. Scand J Infect Dis 1992; 24: 787-791.

26. Rusconi F, Parizzi F, Garlaschi L, et al. Interleukin 6 activity in infants and children with bacterial meningitis. The Collaborative Study on Meningitis. Pediatr Infect Dis J 1991; 10: 117-112.

27. Azuma H, Tsuda N, Sasaki K, Okuno A. Clinical significance of cytokine measurement for detection of meningitis. J Pediatr 1997; 131: 463-465.

28. Mastroianni CM, Paoletti F, Rivosecchi RM, et al. Cerebrospinal fluid interleukin 8 in children with purulent bacterial and tuberculous meningitis. Pediatr Infect Dis J 1994; 13: 1008-1010.

29. Ostergard C, Benfield TL, Sellebjerg F, Kronborg G, Lohse N, Lundgren JD. Interleukin-8 in cerebrospinal fluid from patients with septic and aseptic meningitis. Eur J Clin Microbiol Infect Dis 1996; 15: 166-169.

30. Seki T, Joh K, Oh-ishi T. Augmented production of interleukin-8 in cerebrospinal fluid in bacterial meningitis. Immunology 1993; 80: $333-$ 335.

31. Tsai ML, Chen WC, Wang YC, Hung KL. Cerebrospinal fluid interleukin6 , interleukin-8, and tumor necrosis factor-alpha in children with central nervous system infections. Zhonghua Min Guo Xiao Er Ke Yi Xue Hui Za Zhi 1996; 37: 16-21.

\section{Received 26 April 2004}

Accepted 21 June 2004 


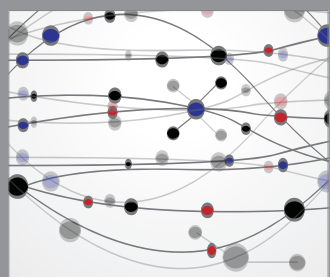

The Scientific World Journal
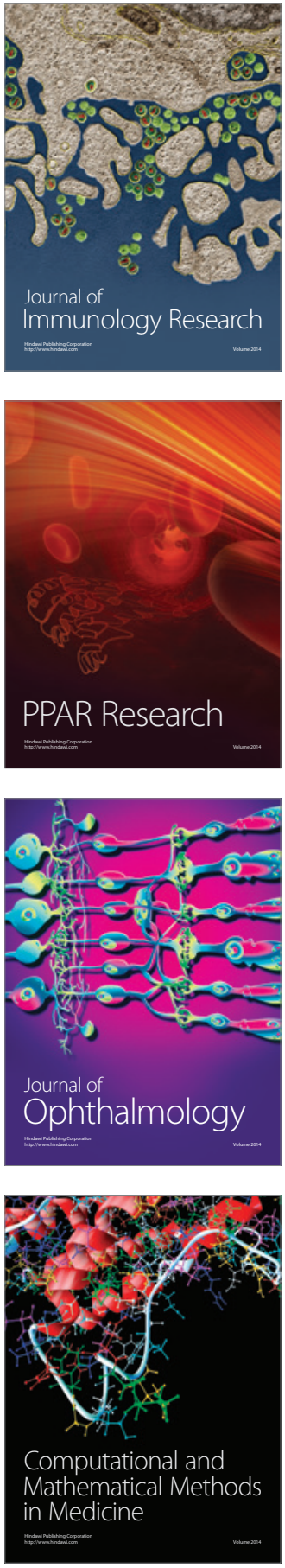

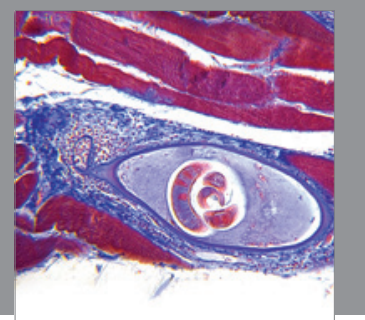

Gastroenterology

Research and Practice
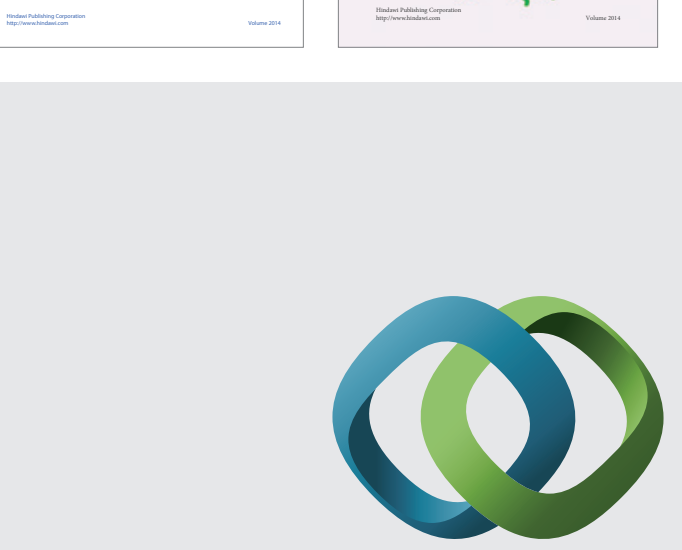

\section{Hindawi}

Submit your manuscripts at

http://www.hindawi.com
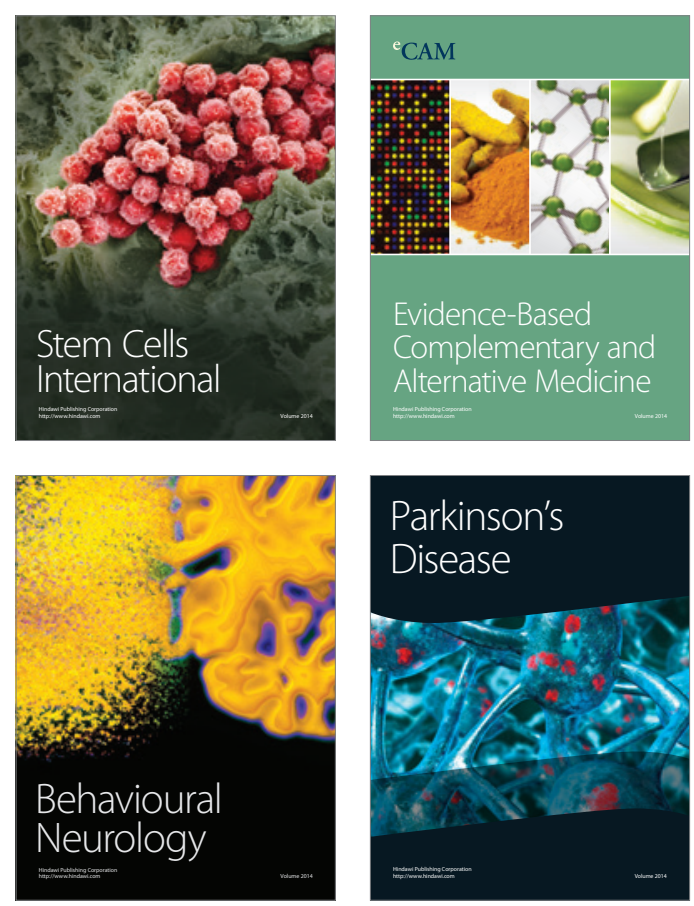

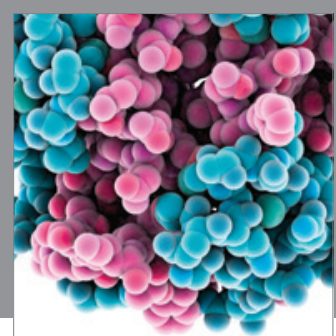

Journal of
Diabetes Research

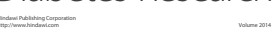

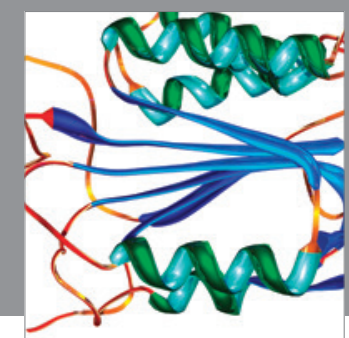

Disease Markers
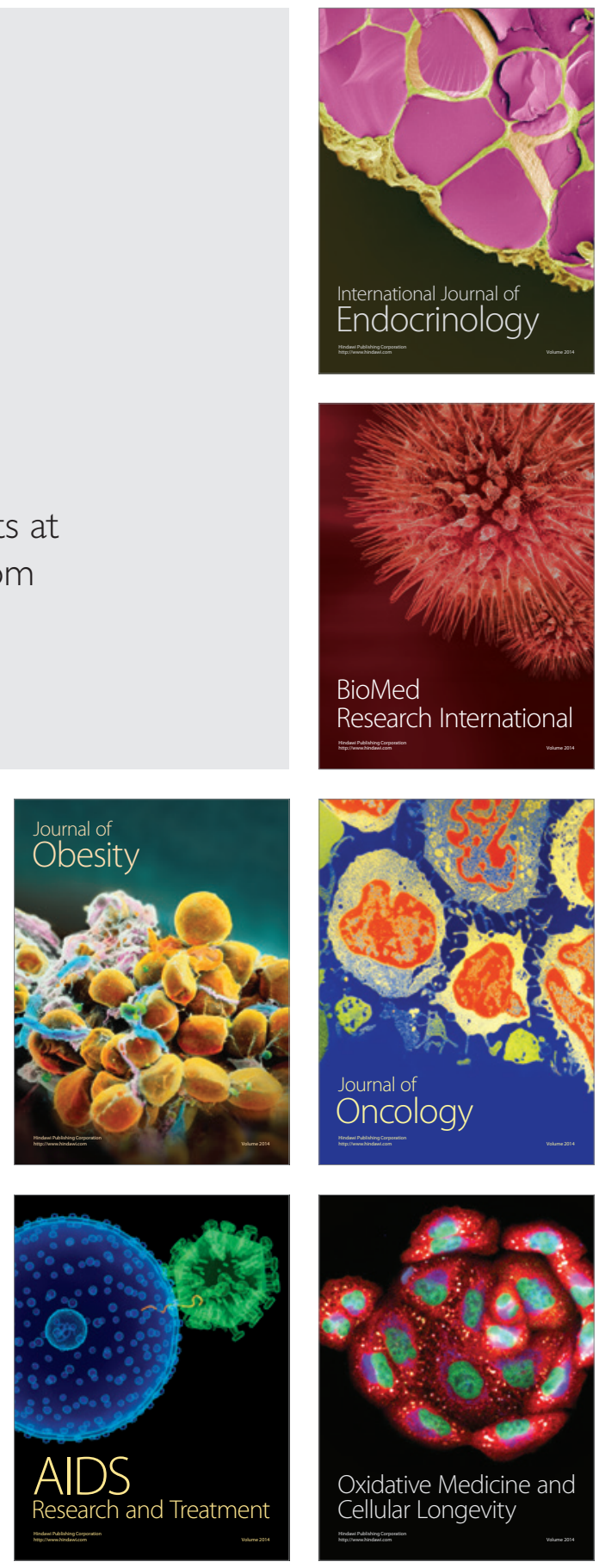